\title{
Theoretical study of the infrared frequencies of crystalline methyl acetate under interstellar medium conditions
}

Radhika Narayanan ${ }^{\mathrm{a}, \mathrm{b}, *}$, Kensuke Inomata ${ }^{\mathrm{a}, \mathrm{b}}$, Geetha Gopakumar ${ }^{\mathrm{a}, \mathrm{b}}$, Bhalamurugan Sivaraman $^{\mathrm{c}}$, Yasunari Zempo ${ }^{\mathrm{d}}$, Masahiko Hada ${ }^{\mathrm{a}, \mathrm{b}}$

${ }^{a}$ Department of Chemistry, Graduate School of Science and Engineering, Tokyo Metropolitan University, 1-1 Minami-Osawa, Hachioji, Tokyo 192-0397, Japan

${ }^{b}$ JST, CREST, 4-1-8 Honcho, Kawaguchi, Saitama 332-0012, Japan

'Space and Atmospheric Sciences Division, Physical Research Laboratory, Ahmedabad 380009, India

${ }^{d}$ Computer and Information Sciences, Hosei University, 3-7-2 Kajino, Koganei 1848584, Japan

* Corresponding author. Tel: $\underline{+81426772554}$

E-mail address: narayanannair-radhika@ed.tmu.ac.jp (R. Narayanan)

\begin{abstract}
Identification of methyl acetate in the interstellar medium (ISM) and its spectroscopic studies have prompted us to investigate the structure of crystalline methyl acetate using numerical calculations. Here, we present a theoretical study of the structure of crystalline methyl acetate and its isotopologues and compare the calculated infrared (IR) spectra with the available experimental data. The optimized structure and vibrational properties were calculated using SIESTA software at $0 \mathrm{~K}$. In the optimization process, the Perdew-Burke-Ernzerhof functional and conjugate gradient method were used with
\end{abstract}


double zeta polarization basis functions. After optimization of the periodic structure, the vibrational frequencies and normal modes were calculated within the harmonic approximation. Using the calculated results, we refine the mode assignments of experimental work on crystalline methyl acetate and determine the low frequency modes (below $650 \mathrm{~cm}^{-1}$ ). To investigate the accuracy of the pseudopotential and confirm the IR frequencies, we performed molecular calculations using a periodic model of methyl acetate and its isotopologues using SIESTA and compared them with results obtained from Gaussian 09 (all electron method) calculations. Finally, we assigned the vibrational modes of crystalline $\mathrm{CD}_{3}-\mathrm{COO}-\mathrm{CH}_{3}$ and $\mathrm{CH}_{3}-\mathrm{COO}-\mathrm{CD}_{3}$, for which experimental data are not available in the crystalline phase under ISM conditions. For all of the calculation methods, the IR vibrational modes of molecular and crystalline methyl acetate and its isotopologues were in good agreement with the available experimental data and predict the unavailable values.

Keywords: Infrared spectra, Methyl acetate, Interstellar medium, DFT 


\section{Introduction}

Methyl acetate $\left(\mathrm{CH}_{3} \mathrm{COOCH}_{3}\right)$ is a colorless and flammable liquid with a pleasant odor. It is a fast evaporating solvent that is highly miscible with most organic solvents, such as alcohols, ketones, glycols, and esters, but only partially soluble in water. Methyl acetate is an environmentally acceptable ester solvent and has been found to be an efficient solvent for radical-mediated processes such as oxidation of alcohols using an $N$-oxy radical catalyst [1]. It is a good organic solvent for various resins and polymers [2], and it is used in the interesterification of triglyceride to produce biodiesel [3].

X-Ray diffraction (XRD) studies were performed on crystalline methyl acetate at $145 \mathrm{~K}$ by Barrow et al [4]. The experiment showed that methyl acetate has monoclinic space group $P 2_{1} / n$ with each unit cell of the crystal containing four molecules arranged in face-centered cubic fashion. Methyl acetate has cis and trans conformers (based on the direction of the $\mathrm{MeO}$ bond with respect to the $\mathrm{C}=\mathrm{O}$ bond), which have different energies $\left(\Delta H^{\circ} \approx 8.5 \pm 1.0 \mathrm{kcal} \mathrm{mol}^{-1}\right)$ [5]. Even though the conformers can interconvert through internal rotation of the $\mathrm{C}-\mathrm{O}$ single bond, the corresponding torsional barrier is relatively high $\left(4457 \mathrm{~cm}^{-1}\right)$ [6]. Hence, it is possible to analyze the vibrational spectra of the stable cis-conformer without considering conformer interconversion.

The gas-phase infrared and microwave spectra of methyl acetate have been reported [5, 7-12]. In addition, the structure and harmonic frequencies have been calculated using $a b$ initio methods, such as second-order Möller-Plesset theory and Hartree-Fock [12-14]. Recently, Senent et al. carried out $a b$ initio calculations using the 
coupled-cluster with single, double, and triple excitations method to calculate the gasphase spectroscopic parameters of methyl acetate [6]. In 2013, Tercero et al. discovered methyl acetate in the Orion constellation in the interstellar medium (ISM) [15]. Based on this identification, Sivaraman et al. carried out vacuum ultraviolet and IR spectroscopic studies of methyl acetate ices in the laboratory under astrochemical conditions [16]. The IR bands of methyl acetate ices could only be assigned based on the available gas-phase calculations. Recently, Das et al. proposed the formation of the isotopologues of methyl acetate $\left(\mathrm{CD}_{3}-\mathrm{COO}-\mathrm{CH}_{3}\right.$ and $\left.\mathrm{CH}_{3}-\mathrm{COO}-\mathrm{CD}_{3}\right)$ in the amorphous phase in the ISM [17].

The unavailability of IR spectroscopic data for the crystalline phase in the low frequency (below $650 \mathrm{~cm}^{-1}$ ) region prompted us to perform quantum-mechanical calculations followed by a detailed analysis of the crystalline phase IR spectra of methyl acetate. The spectroscopic effect of deuteration of the methyl group in the crystalline methyl acetate has not been investigated. To our knowledge, there are no experimental or theoretical IR spectra available for deuterated methyl acetate $\left(\mathrm{CD}_{3}-\mathrm{COO}-\mathrm{CH}_{3}\right.$ and $\left.\mathrm{CH}_{3}-\mathrm{COO}-\mathrm{CD}_{3}\right)$ in the crystalline phase under conditions similar to the ISM environment. Therefore, we calculated the IR spectra of crystalline $\mathrm{CD}_{3}-\mathrm{COO}-\mathrm{CH}_{3}$ and $\mathrm{CH}_{3}-\mathrm{COO}-\mathrm{CD}_{3}$ at $0 \mathrm{~K}$ using the SIESTA code [18] and compared them with the available solid phase data (at liquid nitrogen temperature). To investigate the accuracy of the pseudopotential and numerical atomic orbital method used in the IR calculations in SIESTA, we carried out molecular calculations of methyl acetate and its isotopologues $\left(\mathrm{CD}_{3}-\mathrm{COO}-\mathrm{CH}_{3}\right.$ and $\left.\mathrm{CH}_{3}-\mathrm{COO}-\mathrm{CD}_{3}\right)$ in SIESTA and compared them with results obtained from Gaussian 09 (G09, all electron method) [19] calculations. In this work, we only considered the cis-conformer of methyl acetate for the IR studies, 
and hereafter methyl acetate refers to cis-methyl acetate. The paper is divided into four sections. In Section 2, we describe the computational details. In Section 3, we discuss the results of the theoretical analysis of the molecular and crystalline phase calculations. Finally, we present the conclusions of the study in Section 4.

\section{Computational details}

\subsection{Molecular calculation}

The quantum mechanical calculations of the methyl acetate molecule and its deuterated analogs $\left(\mathrm{CD}_{3}-\mathrm{COO}-\mathrm{CH}_{3}\right.$ and $\left.\mathrm{CH}_{3}-\mathrm{COO}-\mathrm{CD}_{3}\right)$ were performed using the density functional theory (DFT) method. The electronic structure calculations were performed with the G09 software package [19]. The initial structure data for the calculations were obtained from the XRD data of crystalline methyl acetate. The molecular geometries were optimized under C1 symmetry using the Perdew-BurkeErnzerhof (PBE) functional [20] and double- $\zeta$ polarization (DZP) basis set. The 27 fundamental frequencies were calculated at the same level of harmonic approximation. Finally, the vibrational frequencies were obtained by analyzing the forces produced by the finite perturbation method. The absence of imaginary frequencies confirmed that the optimized geometry corresponded to the global minimum.

\subsection{Molecular and crystalline calculation}

The numerical calculations were performed using the SIESTA code [18], which uses a DFT approach along with nonlocal Troullier-Martins norm conserving pseudopotentials [21]. In the calculations, the PBE exchange-correlation functionals of the generalized gradient approximation (GGA) were used. The optimization was carried out using the conjugate gradient method with the DZP basis set. The unit cell 
parameters were fixed to the values determined by XRD and only the atomic positions were relaxed. The orbitals were spatially confined with a cutoff value of $150 \mathrm{meV}$. The force tolerance was fixed to $0.005 \mathrm{eV} \AA^{-1}$ for all of the calculations. The Hartree and exchange-correlation potentials were calculated at the grid points of a mesh with a mesh cutoff value of 400 Ry. After geometry optimization, the vibrational frequencies were obtained using the VIBRA program included in the SIESTA package. The vibrational frequencies and normal modes were calculated within the harmonic approximation from analysis of the forces obtained from finite displacement at $0 \mathrm{~K}$. The frequencies were calculated at the $\Gamma$ point. The normal modes were analyzed with XCrySDen software [22].

To investigate the effect of the pseudopotential, we also performed calculations for an isolated single methyl acetate molecule using a periodic model and compared it with results obtained from a G09 (all electron method) calculation. The methyl acetate molecule was introduced in a large unit cell with lattice parameters $a=10 \AA, b=12 \AA$, $c=10 \AA, \alpha=90^{\circ}, \beta=109^{\circ}$, and $\gamma=90^{\circ}$. The unit cell was made sufficiently large to avoid interaction between neighboring cells. The optimization followed by vibrational analysis was carried out using the parameters mentioned above. The same procedure was repeated for the isotopologues of methyl acetate.

The crystalline methyl acetate structure was constructed with periodic boundary conditions using a unit cell of methyl acetate with lattice parameters $a=7.70 \AA, b=$ $6.96 \AA, c=7.97 \AA, \alpha=90^{\circ}, \beta=109^{\circ}$, and $\gamma=90^{\circ}$ containing four molecules. The vibrational analysis was carried out using the optimized geometry within the harmonic approximation. Using the parameters described for the molecular calculations, optimization and vibrational analyses were carried out. In a similar manner, the IR 
frequencies of crystalline $\mathrm{CD}_{3}-\mathrm{COO}-\mathrm{CH}_{3}$ and $\mathrm{CH}_{3}-\mathrm{COO}-\mathrm{CD}_{3}$ were obtained. The calculated IR spectra were displayed as a Lorentzian function with a half-width at halfmaximum value of $8 \mathrm{~cm}^{-1}$ using Gabedit software [23].

Further, the charge distribution on an isolated single methyl acetate molecule and a molecule in the crystalline solid were estimated with the Voronoi population analysis comprised in the SIESTA program [24, 25].

\section{Results and discussion}

\subsection{Molecular calculation}

\subsubsection{Geometry}

Fig. 1 shows the optimized geometry of the methyl acetate molecule. Selected structural parameters of the optimized structures are compared with the crystallographic data and summarized in Table S1. The internuclear distances calculated with SIESTA are close to the experimental values, except for the $\mathrm{C}_{1}-\mathrm{O}_{1}$ and $\mathrm{C}_{3}-\mathrm{H}_{4}$ bond lengths. The calculated $\mathrm{C}_{2}-\mathrm{O}_{1}$ bond length is reproduced well by both SIESTA and G09 (within $\sim 0.03 \AA$ ). In both the SIESTA and G09 optimized structures, the C-C and C-O bond lengths are within $0.02 \AA$ and $0.03 \AA$ of the experimental values, and the $\mathrm{C}=\mathrm{O}$ bond length is within $0.02 \AA$. The $\mathrm{C}-\mathrm{H}$ bond lengths obtained by both approaches are similar and they are $0.15-0.22 \AA$ longer than the experimental bond lengths. The $\mathrm{O}_{1}-\mathrm{C}_{2}-\mathrm{O}_{2}$, $\mathrm{C}_{2}-\mathrm{C}_{3}-\mathrm{H}_{5}, \mathrm{O}_{1}-\mathrm{C}_{1}-\mathrm{H}_{1}$, and $\mathrm{O}_{1}-\mathrm{C}_{1}-\mathrm{H}_{2}$ bond lengths obtained using SIESTA are closer to the experimental values than those calculated using G09. The rest of the bond angles are well reproduced by G09. Compared with the experimental bond angles, the calculated bond angles are $0.7-4.4^{\circ}$ different, except for $\mathrm{C}_{2}-\mathrm{C}_{3}-\mathrm{H}_{6}\left(\sim 7.5^{\circ}\right)$ and $\mathrm{O}_{1}-\mathrm{C}_{1}-\mathrm{H}_{3}$ 
$\left(\sim 10.3^{\circ}\right)$. Therefore, the bond parameters calculated using G09 and SIESTA are comparable with the values obtained from the XRD study [4].

\subsubsection{Spectroscopic properties}

All of the 27 modes of vibration of the methyl acetate molecule $\left(\mathrm{CH}_{3}-\mathrm{COO}-\right.$ $\left.\mathrm{CH}_{3}\right)$ and its deuterated isotopologues $\left(\mathrm{CD}_{3}-\mathrm{COO}-\mathrm{CH}_{3}\right.$ and $\left.\mathrm{CH}_{3}-\mathrm{COO}-\mathrm{CD}_{3}\right)$ calculated using G09 and SIESTA are reported in Tables 1 and S2 respectively. The experimental frequencies are also shown for comparison. Visual examination of the vibrational oscillations was made using XCrysDen software to confirm the mode of each frequency. The IR spectra of the calculated wavenumbers and intensities of the methyl acetate molecule and its isotopologues are shown in Figs. 2, S1 and S2. In the high-frequency region (above $2000 \mathrm{~cm}^{-1}$ ), the calculated molecular frequencies are higher $\left(\sim 11-82 \mathrm{~cm}^{-1}\right)$ than the experimental values, and the G09 frequencies are closer to the experimental data than the SIESTA frequencies. The calculated frequencies at 1764 (G09) and $1748 \mathrm{~cm}^{-1}$ (SIESTA) are lower than the experimental value and the frequency obtained using G09 is in better agreement with the experimental data, with a small deviation of around $7 \mathrm{~cm}^{-1}$. Below $1500 \mathrm{~cm}^{-1}$, the frequencies obtained from SIESTA are close to the experimental data. In general, the calculated frequencies using both SIESTA and G09 are lower than the experimental data below $1500 \mathrm{~cm}^{-1}$.

Based on the calculated results, the peaks in the high-frequency region (above $\left.2950 \mathrm{~cm}^{-1}\right)$ of the methyl acetate $\left(\mathrm{CH}_{3}-\mathrm{COO}-\mathrm{CH}_{3}\right)$ molecule should be assigned to ${ }^{\mathrm{c}} \mathrm{CH}_{3}$ and ${ }^{\circ} \mathrm{CH}_{3}$ stretching modes. The most intense bands at 1748 and $1228 \mathrm{~cm}^{-1}$ in the SIESTA calculation can be assigned to the $\mathrm{C}=\mathrm{O}$ stretching vibration and skeleton deformation, respectively. The bands in the range $1325-1421 \mathrm{~cm}^{-1}$ (SIESTA) correspond to ${ }^{\circ} \mathrm{CH}_{3}$ and ${ }^{\mathrm{c}} \mathrm{CH}_{3}$ bending modes. It has been reported that the ${ }^{\circ} \mathrm{CH} 3$ and 
${ }^{\mathrm{c}} \mathrm{CH} 3$ rocking modes of the methyl acetate molecule are in the region $976-1275 \mathrm{~cm}^{-1}$ [10]. Our calculated values (in SIESTA) are in the range 959-1154 $\mathrm{cm}^{-1}$. The peaks at 1057, 840 and $637 \mathrm{~cm}^{-1}$ are from $\mathrm{O}-\mathrm{CH}_{3}$ stretching and skeleton deformation. The vibrational bands with peak positions at 576, 414, 319, 215, 170, and $81 \mathrm{~cm}^{-1}$ were assigned to $\mathrm{C}=\mathrm{O}$ wagging, $\mathrm{CCO}$ bending, $\mathrm{COC}$ bending, $\mathrm{C}-\mathrm{O}$ single-bond torsion, ${ }^{\circ} \mathrm{CH}_{3}$ torsion, and ${ }^{\mathrm{C}} \mathrm{CH}_{3}$ torsion, respectively.

We used linear fitting to determine the reliability of the theoretical methods used in the calculations. Fig. S3-S5 shows the correlation between the experimental and theoretical IR frequencies for the methyl acetate molecule and its isotopologues calculated by G09 and SIESTA. The correlation coefficient $(R)$ gives a measure of the linear relationship between the calculated frequencies and the experimental values. Because the $R$ values are close to unity (0.9991 for G09 and 0.9988 for SIESTA in the methyl acetate molecule), there are good linear correlations between the calculated and experimental frequencies, with the G09 results closer to the experimental data than the SIESTA results.

In the IR spectra of the $\mathrm{CD}_{3}-\mathrm{COO}-\mathrm{CH}_{3}$ and $\mathrm{CH}_{3}-\mathrm{COO}-\mathrm{CD}_{3}$ molecules, the peaks observed in the $150-3150 \mathrm{~cm}^{-1}$ region are in good agreement with the bands reported in previous experimental work [10]. The bands with peak positions at 2283, 2321, and $2155 \mathrm{~cm}^{-1}$ in $\mathrm{CD}_{3}-\mathrm{COO}-\mathrm{CH}_{3}$ and 2276, 2313, and $2136 \mathrm{~cm}^{-1}$ in $\mathrm{CH}_{3}-\mathrm{COO}-$ $\mathrm{CD}_{3}$ correspond to ${ }^{\mathrm{C}} \mathrm{CD}_{3}$ and ${ }^{\circ} \mathrm{CD}_{3}$ stretching vibrations. In the IR spectra of these molecules, the bands with highest intensities correspond to $\mathrm{C}=\mathrm{O}$ stretching (1744 and $1746 \mathrm{~cm}^{-1}$ ) and skeleton deformation (1251 and $1242 \mathrm{~cm}^{-1}$ ), respectively. In $\mathrm{CD}_{3}-$ $\mathrm{COO}-\mathrm{CH}_{3}$ and $\mathrm{CH}_{3}-\mathrm{COO}-\mathrm{CD}_{3}$, the calculated frequencies in the range $988-1020 \mathrm{~cm}^{-1}$ correspond to ${ }^{\mathrm{C}} \mathrm{CD}_{3}$ and ${ }^{\circ} \mathrm{CD}_{3}$ bending modes. The $\mathrm{O}-\mathrm{CH}_{3}$ stretching vibration and the 
skeleton deformation vibrations observed at 1071,843 , and $598 \mathrm{~cm}^{-1}$ in $\mathrm{CD}_{3}-\mathrm{COO}-$ $\mathrm{CH}_{3}$ and 1083, 773, and $615 \mathrm{~cm}^{-1}$ in $\mathrm{CH}_{3}-\mathrm{COO}-\mathrm{CD}_{3}$ (all calculations in SIESTA) agree well with the experimental analysis of the IR spectra. The experimental frequencies of these modes are at 1083, 863, and $600 \mathrm{~cm}^{-1}$ in $\mathrm{CD}_{3}-\mathrm{COO}-\mathrm{CH}_{3}$ and 1103, 778, and 621 $\mathrm{cm}^{-1}$ in $\mathrm{CH}_{3}-\mathrm{COO}-\mathrm{CD}_{3}$. The bands observed at 875 and $756 \mathrm{~cm}^{-1}\left(\mathrm{CD}_{3}-\mathrm{COO}-\mathrm{CH}_{3}\right)$, and 876 and $1011 \mathrm{~cm}^{-1}\left(\mathrm{CH}_{3}-\mathrm{COO}-\mathrm{CD}_{3}\right)$ correspond to ${ }^{\mathrm{C}} \mathrm{CD}_{3}$ and ${ }^{\circ} \mathrm{CD}_{3}$ rocking modes. For these molecules, the low-frequency modes below $600 \mathrm{~cm}^{-1}$ can be assigned to $\mathrm{C}=\mathrm{O}$ wagging, bending modes ( $\mathrm{CCO}$ and $\mathrm{COC}$ ), $\mathrm{C}-\mathrm{O}$ single-bond torsion, ${ }^{\mathrm{C}} \mathrm{CD}_{3}$ torsion, and ${ }^{\circ} \mathrm{CD}_{3}$ torsion.

\subsection{Crystalline solid}

\subsubsection{Geometry}

The relevant geometric parameters of crystalline methyl acetate determined from the calculations are listed with the experimental data in Table 2, and the optimized structure is shown in Fig. 3. The calculated geometrical parameters are in good agreement with the experimental values. The $\mathrm{C}-\mathrm{O}$ bond lengths are well reproduced by SIESTA with 0.01-0.03 A difference between the calculated and experimental values. The calculated $\mathrm{C}-\mathrm{C}$ and $\mathrm{C}-\mathrm{H}$ bond lengths are $0.02 \AA$ and $0.15-0.22 \AA$ longer than the experimental values, respectively. The calculated $\mathrm{O}_{1}-\mathrm{C}_{2}-\mathrm{O}_{2}, \mathrm{O}_{1}-\mathrm{C}_{2}-\mathrm{C}_{3}, \mathrm{O}_{2}-\mathrm{C}_{2}-\mathrm{C}_{3}$, and $\mathrm{C}_{1}-\mathrm{O}_{1}-\mathrm{C}_{2}$ bond angles are very close to the experimental values (difference $<0.9^{\circ}$ ). Except for the $\mathrm{C}_{2}-\mathrm{C}_{3}-\mathrm{H}_{6}$ and $\mathrm{O}_{1}-\mathrm{C}_{1}-\mathrm{H}_{3}$ bond angles, the difference between the calculated and experimental bond angles are $<2.9^{\circ}$.

\subsubsection{Spectroscopic properties}

Fig. 4 and Table 3 summarize the calculated IR spectra of crystalline methyl acetate at $0 \mathrm{~K}$ along with the experimental data at 15 and $120 \mathrm{~K}$. Parts (a), (b), and (c) 
show the calculated IR spectra at $0 \mathrm{~K}$ and experimental spectra at 15 and $120 \mathrm{~K}$ [16], respectively. Because there are four methyl acetate molecules per unit cell, the calculated peaks appear in groups of four with the vibrations of similar character grouped together. Similar to the molecular calculation, the theoretical frequencies are overestimated compared with the experimental values above $2900 \mathrm{~cm}^{-1}$ and underestimated below $1750 \mathrm{~cm}^{-1}$. The calculated IR spectrum is in good agreement with the experimental data in terms of the positions of the vibrational frequencies.

The various modes in the high-frequency bands (above $2997 \mathrm{~cm}^{-1}$ in Table 3) can be assigned to ${ }^{\mathrm{C}} \mathrm{CH}_{3}$ and ${ }^{\circ} \mathrm{CH}_{3}$ stretching motions. In the calculated IR spectrum, the strongest peak at $1685 \mathrm{~cm}^{-1}$ can be assigned to the $\mathrm{C}=\mathrm{O}$ stretching vibration and the second strongest peak at $1215 \mathrm{~cm}^{-1}$ to skeleton deformation. The bands in the range 1312-1409 $\mathrm{cm}^{-1}$ (Table 3) can be assigned to ${ }^{\circ} \mathrm{CH}_{3}$ and ${ }^{\mathrm{C}} \mathrm{CH}_{3}$ bending modes, and correspond with the experimental IR bands. Apart from the experimentally measured peaks at 1381,1278 , and $1056 \mathrm{~cm}^{-1}$ in the spectrum measured at $15 \mathrm{~K}$, the assignment of the methyl acetate modes is consistent with the one proposed in the experimental work. The theoretical results indicate that the peaks at $1381(15 \mathrm{~K})$ and $1382 \mathrm{~cm}^{-1}(120$ $\mathrm{K})$ should be ${ }^{\mathrm{C}} \mathrm{CH}_{3}$ bending modes. This is reinforced by earlier work on the solid-state IR spectra of methyl acetate [10], which predicts a ${ }^{\mathrm{c}} \mathrm{CH}_{3}$ bending mode at $1379 \mathrm{~cm}^{-1}$. The bands at $1278(15 \mathrm{~K})$ and $1272 \mathrm{~cm}^{-1}(120 \mathrm{~K})$ correspond to ${ }^{\circ} \mathrm{CH}_{3}$ rocking vibrations, while the previous experimental assignment for this band was $\mathrm{C}-\mathrm{O}$ stretching. Furthermore, the peaks at $1056(15 \mathrm{~K})$ and $1055 \mathrm{~cm}^{-1}(120 \mathrm{~K})$ can be assigned to ${ }^{\mathrm{c}} \mathrm{CH}_{3}$ rocking motions. The bands in the ranges $1111-1145$ and $954-1004 \mathrm{~cm}^{-1}$ (except 992$996 \mathrm{~cm}^{-1}$ ) correspond to ${ }^{\circ} \mathrm{CH}_{3}$ and ${ }^{\mathrm{c}} \mathrm{CH}_{3}$ rocking motions. The $\mathrm{O}-\mathrm{CH}_{3}$ stretching mode and skeleton deformation occur around the frequencies 992-996 and 835-839 $\mathrm{cm}^{-1}$. 
Seven modes lie below $637 \mathrm{~cm}^{-1}$, for which experimental data is not available. They are skeleton deformation, $\mathrm{C}=\mathrm{O}$ wagging, two in-plane bending modes (CCO bending and COC bending), and three out-of plane vibrations ( $\mathrm{C}-\mathrm{O}$ single bond torsion, ${ }^{\circ} \mathrm{CH}_{3}$ torsion, and ${ }^{\mathrm{C}} \mathrm{CH}_{3}$ torsion). Their corresponding harmonic frequencies are in the range 182-637 $\mathrm{cm}^{-1}$.

There is a good linear relationship between the calculated frequencies at $0 \mathrm{~K}$ and the experimental frequencies obtained at 15 and $120 \mathrm{~K}$. Any difference between the theoretical results and the experimental data can be attributed to the anharmonicity of the potential function.

Table 4 list the vibrational frequencies of crystalline $\mathrm{CD}_{3}-\mathrm{COO}-\mathrm{CH}_{3}$ and $\mathrm{CH}_{3}-$ COO- $\mathrm{CD}_{3}$ obtained by SIESTA along with the experimental data. To the best of our knowledge, there have been no experimental measurements of the IR frequencies of these molecules in the crystalline phase under ISM conditions. Hence, we compared the theoretical results in the crystalline phase with the experimental frequencies in the solid phase measured at liquid nitrogen temperature. All of the IR peaks between 150 and $3150 \mathrm{~cm}^{-1}$ in the experimental spectrum were also obtained in the calculations. Figs. 5 and 6 show the calculated IR spectra of crystalline $\mathrm{CD}_{3}-\mathrm{COO}-\mathrm{CH}_{3}$ and $\mathrm{CH}_{3}-\mathrm{COO}-$ $\mathrm{CD}_{3}$. The $\mathrm{D}$ atoms present in the isotopologues of methyl acetate show the same characteristic types of vibrational modes as $\mathrm{H}$ atoms. These include $\mathrm{C}-\mathrm{D}$ stretching, bending, and rocking modes. The vibrational frequencies corresponding to these motions shift to lower frequencies compared with the same $\mathrm{C}-\mathrm{H}$ vibrations because of the larger mass of the $\mathrm{D}$ atom. The ${ }^{\mathrm{c}} \mathrm{CD}_{3}$ and ${ }^{\circ} \mathrm{CD}_{3}$ motions can be easily identified in the IR spectra of $\mathrm{CD}_{3}-\mathrm{COO}-\mathrm{CH}_{3}$ and $\mathrm{CH}_{3}-\mathrm{COO}-\mathrm{CD}_{3}$. Their frequencies decrease in the range $2149-2335 \mathrm{~cm}^{-1}$. In the IR spectra, the peak at $1681 \mathrm{~cm}^{-1}$ in $\mathrm{CD}_{3}-\mathrm{COO}-\mathrm{CH}_{3}$ 
and $1683 \mathrm{~cm}^{-1}$ in $\mathrm{CH}_{3}-\mathrm{COO}-\mathrm{CD}_{3}$ corresponds to the experimentally assigned $\mathrm{C}=\mathrm{O}$ stretching mode. In general, the ${ }^{\circ} \mathrm{CD} 3$ and ${ }^{\mathrm{c}} \mathrm{CD} 3$ bending modes occur at lower frequencies than the experimental results. These peaks appear around $975-1049 \mathrm{~cm}^{-1}$. The skeleton deformation of these molecules $\left(1228-1236 \mathrm{~cm}^{-1}\right.$ for $\mathrm{CD}_{3}-\mathrm{COO}-\mathrm{CH}_{3}$ and 1233-1242 $\mathrm{cm}^{-1}$ for $\mathrm{CH}_{3}-\mathrm{COO}-\mathrm{CD}_{3}$ ) occur at higher frequencies than crystalline methyl acetate $\left(\sim 14 \mathrm{~cm}^{-1}\right.$ higher for $\mathrm{CD}_{3}-\mathrm{COO}-\mathrm{CH}_{3}$ and $\sim 20 \mathrm{~cm}^{-1}$ for $\left.\mathrm{CH}_{3}-\mathrm{COO}-\mathrm{CD}_{3}\right)$. The vibrational bands with peak positions in the range $755-871 \mathrm{~cm}^{-1}$, except for $853-$ $858 \mathrm{~cm}^{-1}$ in $\mathrm{CD}_{3}-\mathrm{COO}-\mathrm{CH}_{3}$ and $864-914 \mathrm{~cm}^{-1}$ in $\mathrm{CH}_{3}-\mathrm{COO}-\mathrm{CD}_{3}$, correspond to ${ }^{\mathrm{c}} \mathrm{CD}_{3}$ and ${ }^{\circ} \mathrm{CD}_{3}$ rocking motions. The bands in the regions 933-938, 992-995, 853-858, and $766-770 \mathrm{~cm}^{-1}$ can be assigned to $\mathrm{O}-\mathrm{CX}_{3}\left(\mathrm{X}=\mathrm{H}\right.$ in $\mathrm{CD}_{3}-\mathrm{COO}-\mathrm{CH}_{3}$ and $\mathrm{X}=\mathrm{D}$ in $\mathrm{CH}_{3}-$ $\left.\mathrm{COO}-\mathrm{CD}_{3}\right)$ stretching modes and skeleton deformation. There are seven vibrational modes below $620 \mathrm{~cm}^{-1}$ : skeleton deformation, $\mathrm{C}=\mathrm{O}$ wagging, two bending modes, $\mathrm{C}-\mathrm{O}$ single bond torsion, ${ }^{\mathrm{C}} \mathrm{CD} 3$ torsion, and ${ }^{\circ} \mathrm{CD} 3$ torsion.

\subsection{Charge distribution analysis}

Table 5 show the atomic charges on an isolated single methyl acetate molecule and a molecule in the crystalline solid estimated with the Voronoi population analysis. In comparison with the isolated molecule and a molecule in the crystalline solid, the electric polarization of the carbonyl part $(\mathrm{C}=\mathrm{O})$ decreases in the crystalline solid. Due to this effect, the $\mathrm{C}=\mathrm{O}$ stretching mode appear at lower frequency in the crystalline solid (Table 1 and 3). Further, the charge on the alkoxy oxygen $\left(\mathrm{O}_{1}\right)$ slightly decreases in the crystalline solid.

\section{Conclusions}


In this work, we investigated the structures and IR spectra of molecular methyl acetate and its deuterated molecules $\left(\mathrm{CD}_{3}-\mathrm{COO}-\mathrm{CH}_{3}\right.$ and $\left.\mathrm{CH}_{3}-\mathrm{COO}-\mathrm{CD}_{3}\right)$ using two different quantum mechanical methods (G09 and SIESTA) and compared the results with the available experimental data. The bond lengths were reproduced well in the SIESTA calculation (pseudopotential) and the bond angles were well produced in the G09 (all electron method) calculation. The calculated molecular frequencies using G09 were closer to the experimental data in the frequency region above $1750 \mathrm{~cm}^{-1}$ than the SIESTA data. Below $1500 \mathrm{~cm}^{-1}$ of the mid-IR region, the DFT molecular calculation with SIESTA was in better agreement with the experimental IR frequencies than G09. Furthermore, there was an excellent linear correlation between the calculated and experimental frequencies.

We calculated the structural parameters and IR spectrum of crystalline phase methyl acetate at $0 \mathrm{~K}$ using SIESTA. The theoretical frequencies were overestimated compared with the experimental values above $2900 \mathrm{~cm}^{-1}$ and underestimated below $1750 \mathrm{~cm}^{-1}$. Using the calculated results, we refined the mode assignments previously reported in experimental work on crystalline methyl acetate and determined the low frequency modes (below $650 \mathrm{~cm}^{-1}$ ). The calculated results indicated that the bands at $1381(15 \mathrm{~K})$ and $1382 \mathrm{~cm}^{-1}$ (120 K) should be assigned to ${ }^{\mathrm{c}} \mathrm{CH} 3$ bending motion. The peaks at $1278(15 \mathrm{~K})$ and $1272 \mathrm{~cm}^{-1}(120 \mathrm{~K})$ are attributed to ${ }^{\circ} \mathrm{CH}_{3}$ rocking mode. The bands at $1056(15 \mathrm{~K})$ and $1055 \mathrm{~cm}^{-1}(120 \mathrm{~K})$ were assigned to ${ }^{\mathrm{c}} \mathrm{CH}_{3}$ rocking motion. The structural and spectroscopic results show that SIESTA is an efficient code for IR determination of crystalline methyl acetate. Moreoever, we calculated the IR spectra of crystalline phase $\mathrm{CD}_{3}-\mathrm{COO}-\mathrm{CH}_{3}$ and $\mathrm{CH}_{3}-\mathrm{COO}-\mathrm{CD}_{3}$ at $0 \mathrm{~K}$ using SIESTA. Using the DFT results, we assigned all of the 27 modes of vibration of $\mathrm{CD}_{3}-\mathrm{COO}-\mathrm{CH}_{3}$ and $\mathrm{CH}_{3}-$ 
COO- $\mathrm{CD}_{3}$, for which experimental data is not available in the crystalline phase under ISM conditions. Finally, the charge distribution analysis in the methyl acetate molecule and crystalline solid shows that the electric polarization of the carbonyl part $(\mathrm{C}=\mathrm{O})$ decreases in the crystalline solid.

This work is an initial step in the calculation of IR frequencies of methyl acetate in the crystalline phase at $0 \mathrm{~K}$. Future calculations will focus on IR vibrational analysis of amorphous methyl acetate and temperature dependent studies.

\section{Acknowledgments}

RN would like to thank the Tokyo Metropolitan Government for supporting the PhD study through the Asian Human Resource Fund Scholarship. RN, KI, GG and MH would like to thank the Core Research for Evolutional Science and Technology (CREST), Japan Science and Technology (JST) Agency, "Creation of Innovative Functions of Intelligent Materials in the basis of the Element Strategy”.

\section{Appendix A. Supplementary data}

Supplementary data associated with this article can be found, in the online version, at

\section{References}

1. M. H. A. Janssen, J. F. C. Castellana, H. Jackman, P. J. Dunn, R. A. Sheldon ,Green Chem. 13 (2011) 905-912.

2. A. Siporska, J. Szydlowski, Macromolecules 41 (2008) 4534-4536.

3. A. Casas, M. J. Ramos, A. Perez, Chem. Eng. J. 171 (2011) 1324-1332. 
4. M. J. Barrow, S. Cradock, E. A. V. Ebsworth, D. W. H. Rankin, J.C.S. Dalton 9 (1981) 1988-1993.

5. C. E. Blom, H. H. Günthard, Chem. Phys. Lett. 84 (1981) 267-271.

6. M. L. Senent, R. Dominguez-Gomez, M. Carvajal, I. Kleiner, J. Chem. Phys. 138 (2013) 044319-044328.

7. B. Nolin, R. N. Jones, Can. J. Chem. 34 (1956) 1382-1391.

8. J. K. Wilmshurst, J. Mol. Spectrosc. 1 (1957) 201-215.

9. T. Shimanouchi, Tables of Molecular Vibrational Frequencies Consolidated (National Bureau of Standards) Vol. I (1972) pp. 1-160.

10. W. O. George, T. E. Houston, W. C. Harris, Spectrochim. Acta Part A 30 (1974) 1035-1057.

11. J. Sheridan, W. Bossert, A. Bauder, J. Mol. Spectrosc. 80 (1980) 1-11.

12. F. X. Sunahori, N. Borho, X. Liu, Y. Xu, J. Chem. Phys. 135 (2011) 234310234317.

13. M. Tudorie, I. Kleiner, J. T. Hougen, S. Melandri, L. W. Sutikdja, W. Stahl, J. Mol. Spectrosc. 269 (2011) 211-225.

14. J. Dybal, S. Krimm, J. Mol. Struct. 189 (1988) 383-392.

15. B. Tercero, I. Kleiner, J. Cernicharo, H. V. L. Nguyen, A. Lopez, G. M. Munoz Caro, Astrophys. J. Lett. 770 (2013) L13.

16. B. Sivaraman, B. G. Nair, J.-I. Lo, S. Kundu, D. Davis, V. Prabhudesai, B. N. Raja Sekhar, N. J. Mason, B.-M. Cheng, E. Krishnakumar, Astrophys. J. 778 (2013) 157.

17. A. Das, L. Majumdar, D. Sahu, P. Gorai, B. Sivaraman, S. K. Chakrabarti, Astrophys. J. 808 (2015) 21. 
18. J. M. Soler, E. Artacho, J. D. Gale, A. Garca, J. Junquera, P. Ordejon, D. Sanchez-Portal, J. Phys. Condens. Matter 14 (2002) 2745-2779.

19. M. J. Frisch, G. W. Trucks, H. B. Schlegel et al., Gaussian 09, Revision A.02, Gaussian Inc., Wallingford, CT, 2009.

20. J. P. Perdew, K. Burke, M. Ernzerhof, Phys. Rev. Lett. 77 (1996) 3865-3868.

21. N. Troullier, J. L. Martins, Phys. Rev. B 43 (1991) 1993-2006.

22. A. Kokalj, Comp. Mater. Sci. 28 (2003) 155-168.

23. A.-R. Allouche, J. Comput. Chem. 32 (2011) 174-182.

24. F. M. Bickelhaupt, N.J. R. van Eikema Hommes, C. F. Guerra, E. J. Baerends, Organometallics 15 (1996) 2923-2931.

25. C. F. Guerra, J.-W. Handgraaf, E. J. Baerends, F. M. Bickelhaupt, J. Comput. Chem. 25 (2004) 189-210.

26. K. Momma, F. Izumi, J. Appl. Crystallogr. 44 (2011) 1272-1276. 
Table 1. Calculated and experimental harmonic fundamental frequencies $\left(\mathrm{cm}^{-1}\right)$ of the methyl acetate $\left(\mathrm{CH}_{3}-\mathrm{COO}-\mathrm{CH}_{3}\right)$ molecule.

\begin{tabular}{|c|c|c|c|c|c|}
\hline \multirow{3}{*}{ Assignment $^{\mathrm{a}}$} & \multicolumn{4}{|c|}{ Calc. } & \multirow{3}{*}{$\begin{array}{l}\text { Expt. } \\
\text { frequency }\end{array}$} \\
\hline & \multicolumn{2}{|c|}{ G09 } & \multicolumn{2}{|c|}{ SIESTA } & \\
\hline & Frequency & Intensity $^{\mathrm{C}}$ & Frequency & Intensity $^{\mathrm{C}}$ & \\
\hline${ }^{\mathrm{c}} \mathrm{CH}_{3} \mathrm{st}$ & 3104 & 0.008 & 3128 & 0.026 & 3040 \\
\hline${ }^{\circ} \mathrm{CH}_{3}$ st & 3088 & 0.034 & 3114 & 0.087 & 3040 \\
\hline${ }^{\mathrm{c}} \mathrm{CH}_{3} \mathrm{st}$ & 3064 & 0.010 & 3086 & 0.017 & 3000 \\
\hline${ }^{\circ} \mathrm{CH}_{3}$ st & 3047 & 0.060 & 3068 & 0.068 & 3000 \\
\hline${ }^{\mathrm{c}} \mathrm{CH}_{3} \mathrm{st}$ & 2979 & 0.006 & 2998 & 0.000 & 2940 \\
\hline${ }^{\circ} \mathrm{CH}_{3} \mathrm{st}$ & 2961 & 0.102 & 2981 & 0.008 & 2961 \\
\hline $\mathrm{C}=\mathrm{O}$ st & 1764 & 0.834 & 1748 & 0.745 & 1771 \\
\hline${ }^{\circ} \mathrm{CH}_{3} \mathrm{~b}$ & 1415 & 0.029 & 1421 & 0.000 & 1467 \\
\hline${ }^{\mathrm{c}} \mathrm{CH}_{3} \mathrm{~b}$ & 1401 & 0.091 & 1400 & 0.046 & 1446 \\
\hline${ }^{\circ} \mathrm{CH}_{3} \mathrm{~b}$ & 1397 & 0.029 & 1406 & 0.035 & 1459 \\
\hline${ }^{\mathrm{c}} \mathrm{CH}_{3} \mathrm{~b}$ & 1394 & 0.049 & 1394 & 0.013 & 1439 \\
\hline${ }^{\circ} \mathrm{CH}_{3} \mathrm{~b}$ & 1385 & 0.028 & 1388 & 0.076 & 1439 \\
\hline${ }^{\mathrm{c}} \mathrm{CH}_{3} \mathrm{~b}$ & 1320 & 0.236 & 1325 & 0.219 & 1378 \\
\hline Skel. def. & 1219 & 1.000 & 1228 & 1.000 & 1246 \\
\hline${ }^{\circ} \mathrm{CH}_{3} \mathrm{r}$ & 1146 & 0.006 & 1154 & 0.038 & 1275 \\
\hline${ }^{\circ} \mathrm{CH}_{3} \mathrm{r}$ & 1113 & 0.000 & 1123 & 0.003 & 1194 \\
\hline $\mathrm{O}-\mathrm{CH}_{3} \mathrm{st}$ & 1038 & 0.178 & 1057 & 0.201 & 1058 \\
\hline${ }^{\mathrm{c}} \mathrm{CH}_{3} \mathrm{r}$ & 1001 & 0.029 & 1006 & 0.034 & 1058 \\
\hline${ }^{\mathrm{c}} \mathrm{CH}_{3} \mathrm{r}$ & 955 & 0.004 & 959 & 0.000 & 976 \\
\hline Skel. def. & 830 & 0.064 & 840 & 0.103 & 842 \\
\hline Skel. def. & 628 & 0.015 & 637 & 0.017 & 634 \\
\hline $\mathrm{C}=\mathrm{O} \mathrm{w}$ & 580 & 0.010 & 576 & 0.006 & 525 \\
\hline CCO b & 411 & 0.018 & 414 & 0.020 & 427 \\
\hline COC b & 277 & 0.039 & 319 & 0.072 & 295 \\
\hline Tor & 180 & 0.022 & 215 & 0.033 & 203 \\
\hline${ }^{\circ} \mathrm{CH}_{3} \mathrm{~T}$ & 133 & 0.001 & 170 & 0.002 & - \\
\hline${ }^{\mathrm{c}} \mathrm{CH}_{3} \mathrm{~T}$ & 33 & 0.000 & 81 & 0.006 & - \\
\hline
\end{tabular}

${ }^{a}$ Assignment of the vibrational modes: st, stretching; b, bending; r, rocking; T, torsion; w, wagging; and Skel. def., skeleton deformation.

${ }^{\mathrm{b}}$ Experimental data from Ref. 10.

${ }^{\mathrm{c}}$ The relative intensities are obtained by normalizing with the strongest band of each set. 
Table 2. Selected calculated and experimental structural parameters of crystalline methyl acetate $\left(\mathrm{CH}_{3}-\mathrm{COO}-\mathrm{CH}_{3}\right)$.

\begin{tabular}{ccc}
\hline Structural parameters & Calc. & Expt. $^{\text {a }}$ \\
\hline $\mathrm{C}_{1}-\mathrm{O}_{1}$ & Bond length $(\AA)$ & 1.4529 \\
$\mathrm{C}_{1}-\mathrm{H}_{1}$ & 1.4537 & 0.9052 \\
$\mathrm{C}_{1}-\mathrm{H}_{2}$ & 1.1082 & 0.9482 \\
$\mathrm{C}_{1}-\mathrm{H}_{3}$ & 1.1098 & 0.9525 \\
$\mathrm{C}_{2}-\mathrm{O}_{1}$ & 1.1073 & 1.3376 \\
$\mathrm{C}_{2}-\mathrm{O}_{2}$ & 1.3519 & 1.1999 \\
$\mathrm{C}_{2}-\mathrm{C}_{3}$ & 1.2323 & 1.4929 \\
$\mathrm{C}_{3}-\mathrm{H}_{4}$ & 1.5139 & 0.8885 \\
$\mathrm{C}_{3}-\mathrm{H}_{5}$ & 1.1039 & 0.9480 \\
$\mathrm{C}_{3}-\mathrm{H}_{6}$ & 1.1099 & 0.9562 \\
\hline $\mathrm{O}_{1}-\mathrm{C}_{2}-\mathrm{O}_{2}$ & 1.1140 & 122.53 \\
$\mathrm{O}_{1}-\mathrm{C}_{2}-\mathrm{C}_{3}$ & 122.62 & 111.76 \\
$\mathrm{O}_{2}-\mathrm{C}_{2}-\mathrm{C}_{3}$ & 112.63 & 125.68 \\
$\mathrm{C}_{1}-\mathrm{O}_{1}-\mathrm{C}_{2}$ & 124.75 & 114.86 \\
$\mathrm{C}_{2}-\mathrm{C}_{3}-\mathrm{H}_{4}$ & 114.36 & 113.53 \\
$\mathrm{C}_{2}-\mathrm{C}_{3}-\mathrm{H}_{5}$ & 112.16 & 105.66 \\
$\mathrm{C}_{2}-\mathrm{C}_{3}-\mathrm{H}_{6}$ & 108.51 & 101.36 \\
$\mathrm{O}_{1}-\mathrm{C}_{1}-\mathrm{H}_{1}$ & 108.57 & 106.51 \\
$\mathrm{O}_{1}-\mathrm{C}_{1}-\mathrm{H}_{2}$ & 109.37 & 108.9 \\
$\mathrm{O}_{1}-\mathrm{C}_{1}-\mathrm{H}_{3}$ & 110.29 & 95.36 \\
\hline
\end{tabular}

${ }^{\mathrm{a}}$ Experimental values from Ref.4. 
Table 3. Calculated and experimental harmonic fundamental frequencies $\left(\mathrm{cm}^{-1}\right)$ of crystalline methyl acetate $\left(\mathrm{CH}_{3}-\mathrm{COO}-\mathrm{CH}_{3}\right)$.

\begin{tabular}{|c|c|c|c|c|c|c|}
\hline \multirow{2}{*}{ Assignment ${ }^{\mathrm{a}}$} & \multicolumn{2}{|c|}{ Calc. (0 K) } & \multicolumn{2}{|c|}{ Expt. $(15 \mathrm{~K})^{\mathrm{b}}$} & \multicolumn{2}{|c|}{ Expt. $(120 \mathrm{~K})^{\mathrm{b}}$} \\
\hline & Frequency & Intensity $^{\mathrm{c}}$ & Frequency & Intensity $^{\mathrm{c}}$ & Frequency & Intensity $^{\mathrm{c}}$ \\
\hline${ }^{\mathrm{c}} \mathrm{CH} 3 \mathrm{st}$ & $3147-3145$ & 0.005 & 3031 & 0.194 & 3030 & 0.173 \\
\hline${ }^{\circ} \mathrm{CH} 3$ st & $3125-3123$ & 0.000 & 3001 & 0.280 & 3002 & 0.284 \\
\hline${ }^{\circ} \mathrm{CH} 3$ st & 3103-3100 & 0.008 & 2988 & 0.153 & - & - \\
\hline${ }^{\circ} \mathrm{CH} 3 \mathrm{st}$ & 3072-3070 & 0.003 & 3022 & 0.192 & - & - \\
\hline${ }^{\circ} \mathrm{CH} 3$ st & 3010-3004 & 0.011 & 2959 & 0.241 & 2957 & 0.234 \\
\hline${ }^{\mathrm{c}} \mathrm{CH} 3 \mathrm{st}$ & 2997-2986 & 0.006 & 2941 & 0.150 & 2942 & 0.138 \\
\hline $\mathrm{C}=\mathrm{O}$ st & $1701-1679$ & 1.000 & 1726 & 1.000 & 1729 & 1.000 \\
\hline${ }^{\circ} \mathrm{CH} 3 \mathrm{~b}$ & 1409-1398 & 0.000 & 1469 & 0.717 & 1468 & 0.570 \\
\hline${ }^{\circ} \mathrm{CH} 3 \mathrm{~b}$ & 1386-1381 & 0.000 & 1457 & 0.563 & - & - \\
\hline${ }^{\mathrm{c}} \mathrm{CH} 3 \mathrm{~b}$ & 1397-1391 & 0.069 & 1449 & 0.773 & 1447 & 0.712 \\
\hline${ }^{\circ} \mathrm{CH} 3 \mathrm{~b}$ & 1373-1371 & 0.031 & 1439 & 0.661 & - & - \\
\hline${ }^{\mathrm{c}} \mathrm{CH} 3 \mathrm{~b}$ & 1356-1355 & 0.000 & 1381 & 0.737 & 1382 & 0.681 \\
\hline${ }^{\mathrm{c}} \mathrm{CH} 3 \mathrm{~b}$ & 1320-1312 & 0.104 & 1365 & 0.247 & 1365 & 0.245 \\
\hline Skel. def. & 1222-1209 & 0.596 & 1240 & 0.763 & 1240 & 0.772 \\
\hline${ }^{\circ} \mathrm{CH} 3 \mathrm{r}$ & 1145-1143 & 0.028 & 1278 & 0.318 & 1272 & 0.325 \\
\hline${ }^{\circ} \mathrm{CH} 3 \mathrm{r}$ & $1112-1111$ & 0.000 & 1186 & 0.503 & 1186 & 0.364 \\
\hline${ }^{\mathrm{c}} \mathrm{CH} 3 \mathrm{r}$ & 1004-1002 & 0.003 & 1056 & 0.488 & 1055 & 0.459 \\
\hline $\mathrm{O}-\mathrm{CH} 3 \mathrm{st}$ & 996-992 & 0.034 & 1048 & 0.614 & 1048 & 0.539 \\
\hline${ }^{\mathrm{c}} \mathrm{CH} 3 \mathrm{r}$ & $960-954$ & 0.125 & 990 & 0.355 & 989 & 0.249 \\
\hline Skel. def. & 839-835 & 0.076 & 853 & 0.299 & 852 & 0.321 \\
\hline Skel. def. & 637-629 & 0.001 & - & - & - & - \\
\hline $\mathrm{C}=\mathrm{O} \mathrm{w}$ & 606-601 & 0.018 & - & - & - & - \\
\hline $\mathrm{CCO} b$ & 420-409 & 0.025 & - & - & - & - \\
\hline $\mathrm{COC} b$ & $321-303$ & 0.012 & - & - & - & - \\
\hline Tor & $243-227$ & 0.020 & - & - & - & - \\
\hline${ }^{\circ} \mathrm{CH} 3 \mathrm{~T}$ & 220-198 & 0.035 & - & - & - & - \\
\hline${ }^{\mathrm{c}} \mathrm{CH} 3 \mathrm{~T}$ & 196-182 & 0.005 & - & - & - & - \\
\hline
\end{tabular}

${ }^{a}$ Assignment of the vibrational modes: st, stretching; b, bending; r, rocking; T, torsion, w, wagging; and Skel. def., skeleton deformation.

${ }^{\mathrm{b}}$ Experimental crystalline phase data from Ref. 16.

${ }^{\mathrm{c}}$ The relative intensities are obtained by normalizing with the strongest band of each set. 
Table 4. Calculated and experimental harmonic fundamental frequencies $\left(\mathrm{cm}^{-1}\right)$ of crystalline $\mathrm{CD}_{3}-\mathrm{COO}-\mathrm{CH}_{3}$ and $\mathrm{CH}_{3}-\mathrm{COO}-\mathrm{CD}_{3}$.

\begin{tabular}{|c|c|c|c|c|c|c|}
\hline \multirow{4}{*}{ Assignment ${ }^{\mathrm{a}}$} & \multicolumn{3}{|c|}{$\mathrm{CD}_{3}-\mathrm{COO}-\mathrm{CH}_{3}$} & \multicolumn{3}{|c|}{$\mathrm{CH}_{3}-\mathrm{COO}-\mathrm{CD}_{3}$} \\
\hline & \multicolumn{2}{|c|}{ Calc. } & \multirow{2}{*}{$\begin{array}{c}\text { Expt. }^{\mathrm{b}} \\
\text { Solid phase }\end{array}$} & \multicolumn{2}{|c|}{ Calc. } & \multirow{2}{*}{$\begin{array}{c}\text { Expt. }^{\mathrm{b}} \\
\text { Solid phase }\end{array}$} \\
\hline & \multicolumn{2}{|c|}{ Crystalline phase } & & \multicolumn{2}{|c|}{ Crystalline phase } & \\
\hline & Frequency & Intensity $^{\mathrm{c}}$ & Frequency & Frequency & Intensity $^{\mathrm{c}}$ & Frequency \\
\hline${ }^{\mathrm{c}} \mathrm{CX}_{3}$ st & 2335-2334 & 0.000 & 2258 & $3147-3145$ & 0.005 & - \\
\hline${ }^{\circ} \mathrm{CX}_{3}$ st & $3125-3123$ & 0.000 & 3032 & $2321-2320$ & 0.004 & 2276 \\
\hline${ }^{\circ} \mathrm{CX}_{3}$ st & 3103-3101 & 0.010 & 3001 & 2303-2301 & 0.006 & 2200 \\
\hline${ }^{\mathrm{c}} \mathrm{CX}_{3}$ st & $2270-2268$ & 0.001 & 2177 & $3072-3070$ & 0.004 & - \\
\hline${ }^{\circ} \mathrm{CX}_{3}$ st & 3010-3002 & 0.016 & 2957 & 2154-2149 & 0.002 & 2085 \\
\hline${ }^{\mathrm{c}} \mathrm{CX}_{3}$ st & $2157-2150$ & 0.035 & - & $2997-2988$ & 0.058 & - \\
\hline $\mathrm{C}=\mathrm{O}$ st & 1698-1676 & 1.000 & 1718 & 1698-1677 & 1.000 & 1723 \\
\hline${ }^{\circ} \mathrm{CX}$ b & 1398-1394 & 0.000 & 1463 & $1032-1024$ & 0.000 & - \\
\hline${ }^{\circ} \mathrm{CX}_{3} \mathrm{~b}$ & 1388-1384 & 0.000 & - & 1014-1009 & 0.001 & 1053 \\
\hline${ }^{\mathrm{c}} \mathrm{CX} \mathrm{X}_{3} \mathrm{~b}$ & 1049-1037 & 0.000 & 1032 & 1393-1386 & 0.000 & - \\
\hline${ }^{\circ} \mathrm{CX}_{3} \mathrm{~b}$ & 1380-1378 & 0.000 & 1440 & 1005-1003 & 0.008 & - \\
\hline${ }^{\mathrm{c}} \mathrm{CX}_{3} \mathrm{~b}$ & 989-985 & 0.019 & 1032 & $1358-1357$ & 0.000 & 1438 \\
\hline${ }^{\mathrm{c}} \mathrm{CX}_{3} \mathrm{~b}$ & 978-975 & 0.001 & 993 & $1320-1313$ & 0.133 & 1379 \\
\hline Skel. def. & $1236-1228$ & 0.648 & 1263 & $1242-1233$ & 0.572 & 1270 \\
\hline${ }^{\circ} \mathrm{CX}_{3} \mathrm{r}$ & 1149-1146 & 0.048 & 1280 & 914-908 & 0.004 & - \\
\hline${ }^{\circ} \mathrm{CX}_{3} \mathrm{r}$ & $1112-1111$ & 0.000 & 1204 & 865-864 & 0.004 & 894 \\
\hline${ }^{\mathrm{c}} \mathrm{CX}_{3} \mathrm{r}$ & $871-869$ & 0.033 & 922 & $986-984$ & 0.027 & 1044 \\
\hline $\mathrm{O}-\mathrm{CX}_{3} \mathrm{st}$ & 938-933 & 0.005 & 1083 & 995-992 & 0.001 & 1093 \\
\hline${ }^{\mathrm{c}} \mathrm{CX}_{3} \mathrm{r}$ & $763-755$ & 0.000 & 788 & $1002-1000$ & 0.001 & 948 \\
\hline Skel. def & 858-853 & 0.000 & - & $770-766$ & 0.013 & 787 \\
\hline Skel. def. & 596-588 & 0.004 & 601 & $620-613$ & 0.004 & 622 \\
\hline $\mathrm{C}=\mathrm{O} \mathrm{w}$ & $531-527$ & 0.018 & 538 & 598-592 & 0.016 & - \\
\hline $\mathrm{CCO} \mathrm{b}$ & $388-380$ & 0.029 & 406 & $411-400$ & 0.019 & - \\
\hline $\mathrm{COC} b$ & $307-291$ & 0.000 & - & $297-280$ & 0.013 & - \\
\hline Tor & $234-220$ & 0.000 & 208 & 222-199 & 0.033 & 200 \\
\hline${ }^{\circ} \mathrm{CX}_{3} \mathrm{~T}$ & 212-190 & 0.034 & - & 198-177 & 0.002 & - \\
\hline${ }^{\mathrm{c}} \mathrm{CX}_{3} \mathrm{~T}$ & $160-146$ & 0.000 & - & $166-157$ & 0.000 & - \\
\hline
\end{tabular}

$\mathrm{X}=\mathrm{H}$ or $\mathrm{D}$

${ }^{a}$ Assignment of the vibrational modes: st, stretching; b, bending; r, rocking; $\mathrm{T}$, torsion; $\mathrm{w}$, wagging; and Skel. def., skeleton deformation. 
${ }^{\mathrm{b}}$ Experimental solid phase data from Ref. 10 .

${ }^{\mathrm{c}}$ The relative intensities are obtained by normalizing with the strongest band of each set.

Table 5. Voronoi population analysis in isolated single methyl acetate molecule and a molecule in the crystalline solid.

\begin{tabular}{ccc}
\hline Atom $^{\mathrm{a}}$ & Isolated molecule & Molecule in crystal \\
\hline $\mathrm{C}_{1}$ & 0.068 & 0.068 \\
$\mathrm{O}_{1}$ & -0.082 & -0.057 \\
$\mathrm{C}_{2}$ & 0.189 & 0.206 \\
$\mathrm{O}_{2}$ & -0.245 & -0.219 \\
$\mathrm{C}_{3}$ & -0.036 & -0.042 \\
$\mathrm{H}_{1}$ & 0.006 & -0.004 \\
$\mathrm{H}_{2}$ & 0.005 & -0.002 \\
$\mathrm{H}_{3}$ & 0.015 & 0.008 \\
$\mathrm{H}_{4}$ & 0.023 & 0.003 \\
$\mathrm{H}_{5}$ & 0.028 & 0.016 \\
$\mathrm{H}_{6}$ & 0.030 & 0.023 \\
\hline
\end{tabular}

${ }^{\mathrm{a}}$ atom numbers are defined in the Fig. 1. 


\section{Figure captions}

Fig. 1. Optimized structure of methyl acetate $\left(\mathrm{CH}_{3}-\mathrm{COO}-\mathrm{CH}_{3}\right)$ at the $\mathrm{PBE}$ level. (Molecular structure drawn using VESTA [26]).

Fig. 2. IR spectra of the methyl acetate molecule $\left(\mathrm{CH}_{3}-\mathrm{COO}-\mathrm{CH}_{3}\right)$ calculated using G09 and SIESTA.

Fig. 3. Structure of crystalline methyl acetate $\left(\mathrm{CH}_{3}-\mathrm{COO}-\mathrm{CH}_{3}\right)$. (Crystalline structure drawn using VESTA [26]).

Fig. 4. Comparison of the IR spectra of crystalline methyl acetate $\left(\mathrm{CH}_{3}-\mathrm{COO}-\mathrm{CH}_{3}\right)$ : (a) calculated at $0 \mathrm{~K}$ and the experimental spectra at (b) $15 \mathrm{~K}$ and (c) $120 \mathrm{~K}$.

Fig. 5. IR spectrum of crystalline $\mathrm{CD}_{3}-\mathrm{COO}-\mathrm{CH}_{3}$.

Fig. 6. IR spectrum of crystalline $\mathrm{CH}_{3}-\mathrm{COO}-\mathrm{CD}_{3}$. 


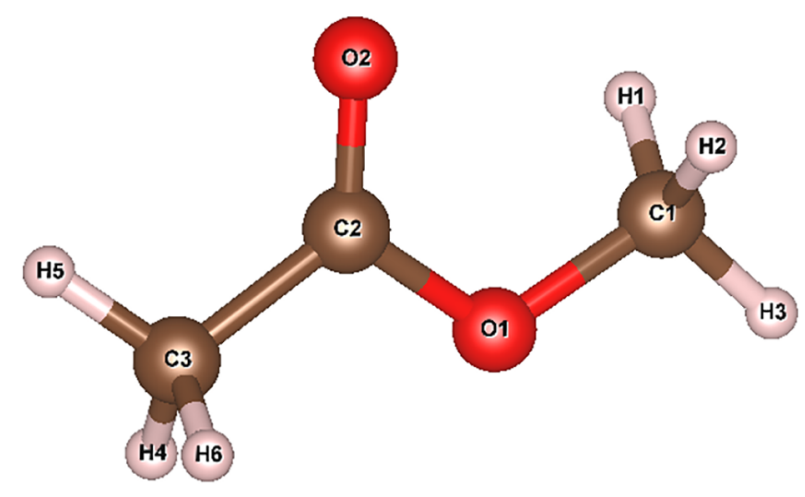

Fig. 1. 


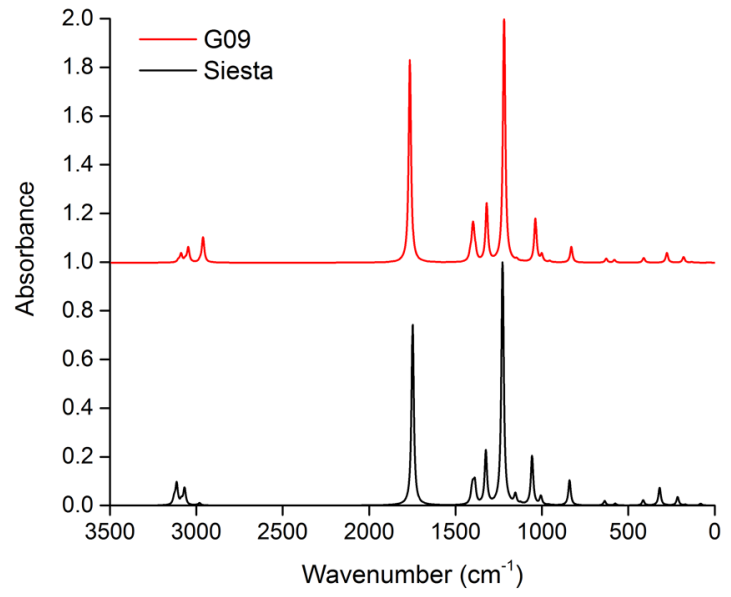

Fig. 2. 


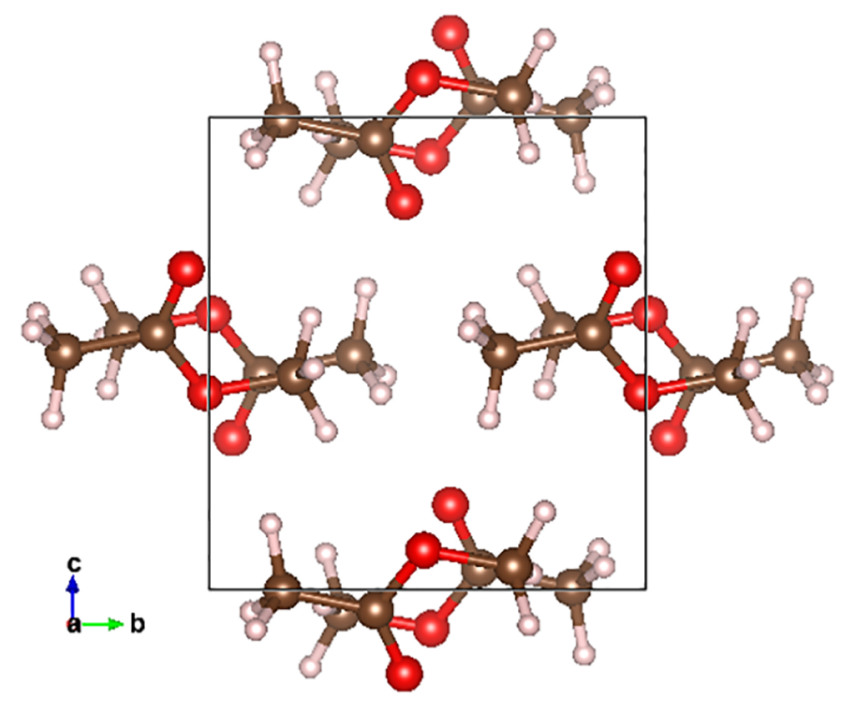

Fig. 3. 

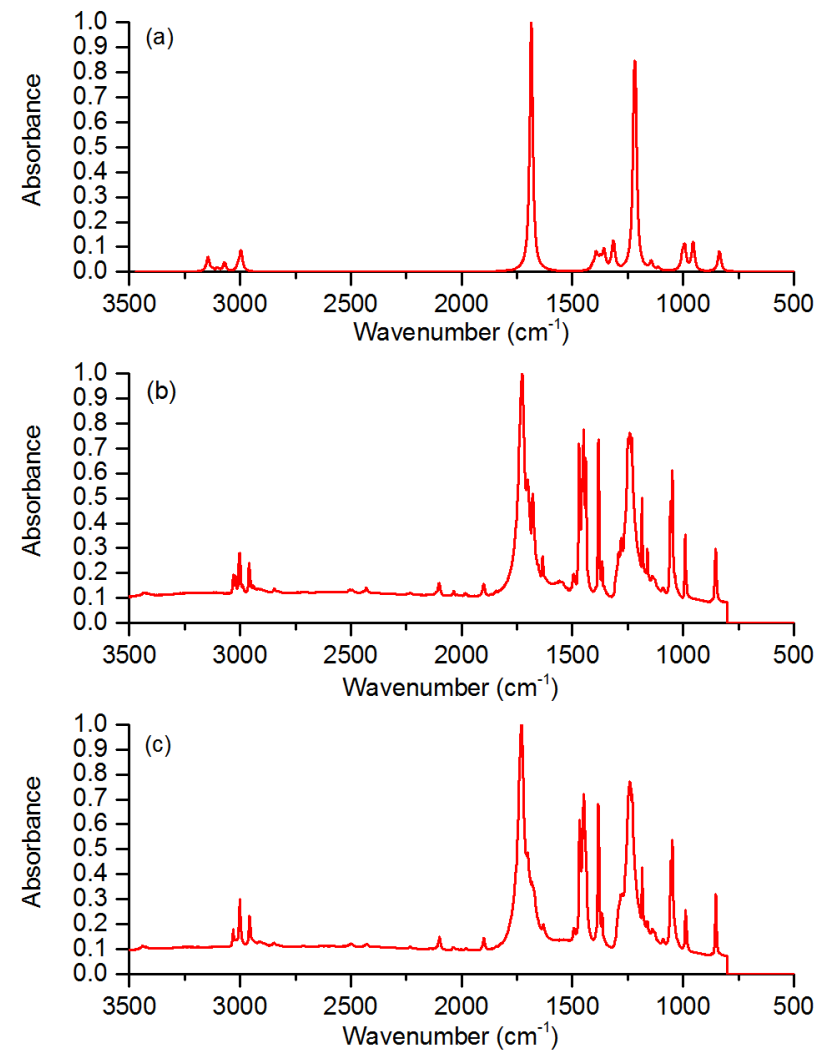

Fig. 4. 


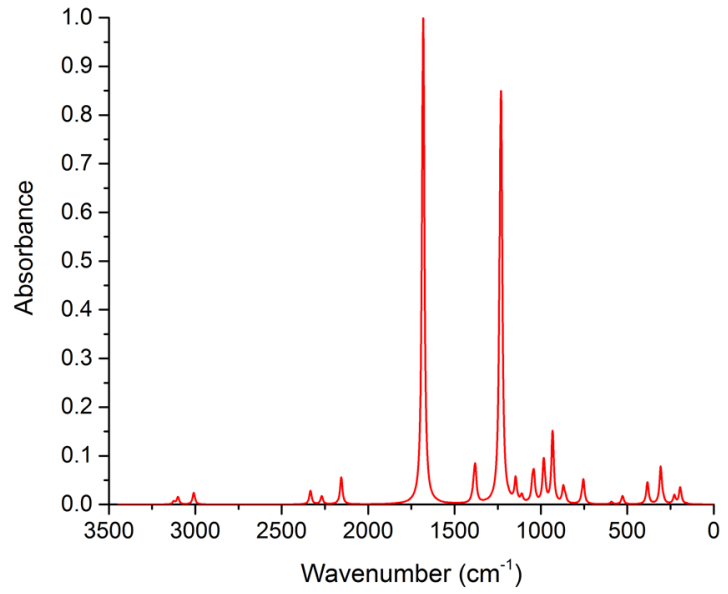

Fig. 5. 


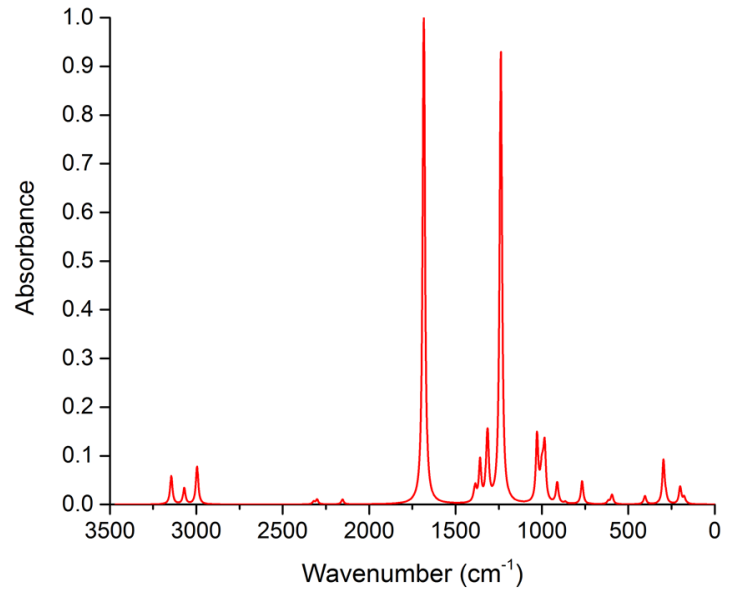

Fig. 6. 
